\title{
Conjuring Machinic Life
}

\author{
Natasha Myers*
}

"Captured" in the hands of twenty-first-century structural biologists, "life itself" is taking on new form. The current trend towards molecularization in the life sciences is generating forms of life that are denser than the one-dimensional logic of a genetic code. "Life itself" now appears to have a multidimensional material body, and as the story goes, its molecular structures, forces, and movements carry out the regulated work of the cell. Researchers are no longer satisfied reducing the organism to the logic of coding systems embedded in computer software (e.g. Harrison 2004); the organism now has a mechanical architecture, and its molecular mechanisms have come to resemble the many kinds of machines with which we currently live and work (see also Keller 1995; Fujimura 2005). These include electronic circuitry, and the levers, switches, hinges, springs, locks, and clamps of modern day mechanical devices. These are the molecular machines that populate what is fast becoming the factory-floor of the cell. ${ }^{1}$

Yet, molecular machines are not the inventions of twenty-first century technoscience. In the nineteenth century Thomas Henry Huxley developed a mechanical theory of the cell that he peddled as the "protoplasmic theory of life" (see Geison 1969; Huxley 1878). He argued that life must be analyzed according to its chemical and physical properties, and in 1880, the Encyclopaedia Britannica published Huxley's definitive entry on "Biology." It was here that Huxley took the opportunity to display his way of thinking about the stuff of life. He explained:

A mass of living protoplasm is simply a molecular machine of great complexity, the total results of the working of which, or its vital phenomena, depend, on the one hand upon its construction, and, on the other, upon the energy supplied to it; and to speak of vitality as anything but the

\footnotetext{
* Natasha Myers is an Assistant Professor in Anthropology and Science and Technology Studies at York University. In her research, she examines the lively visual and performance cultures that thrive in contemporary life science laboratories and classrooms. She is currently completing an ethnography entitled Modeling Proteins, Making Scientists: Pedagogy and Visual Cultures in Contemporary Structural Biology.

${ }^{1}$ The following essay is a short excerpt from Myers, "Modeling Molecular Machines," which is forthcoming in Sharon Ghamari-Tabrizi (ed) NatureCultures: Thinking with Donna Haraway, Cambridge, MA: MIT Press, 2009.
} 
name of a series of operations, is as if one should talk of the 'horologity' of a clock (Huxley 1878, 15).

In light of recent developments in structural biology and biological engineering, Huxley's parsing of the protoplasm, and indeed, the phenomenon of life, as a working machine whose parts must be supplied with energy, would not make today's audiences swerve. Huxley's contemporaries, however, took great exception to the analogy and its implications for vital phenomena. Lionel Beale, who was the president of the Royal Microscopial Society, and one of Huxley's most prominent opponents, argued against the mechanization of life (see Gieson 1969). In his annual address to the society in 1881 he voiced this strong objection to Huxley:

This is the sort of teaching that has long retarded the progress of thought, and affords an example of the puerile objections palmed off on the public as scientific criticism, and supposed to be sufficient to controvert evidence founded upon observation, and arguments based on facts which any one may demonstrate. It is not most wonderful that Professor Huxley can persuade himself that a single reader of intelligence will fail to see the absurdity of the comparison he institutes between the invisible, undemonstrable, undiscovered "machinery" of his suppositious "molecular machine" and the actual visible works of the actual clock, which any one can see and handle, and stop and cause to go on again (Beale 1881, 297; emphasis added).

Similarly for JW Dawson, a former president of the American Association for the Advancement of Science, it would "scarcely be possible" in the space of Huxley's Encyclopaedia entry, "to put into the same number of words a greater amount of unscientific assumption and unproved statement" (Dawson 1883, 195). The main complaint of Huxley's critics was that, given the limits of microscopic vision, "molecular machines" could be no more than an elaborate fantasy. According to Beale, "magnify living matter as we may, nothing can be demonstrated but an extremely delicate, transparent, apparently semi-fluid substance ... consisting of infinite numbers of infinitely minute particles ... capable of coalescing, free to move amongst one another" (1881, 279). To identify invisible and intangible substances as machines represented at best a kind of catachresis: in this sense, a metaphor that lacks a concrete referent (see Kay 2000). For Huxley's opponents, human-scale machines were real, but molecule-sized machines a fiction. For molecular machines to exist they had to have, like a clock, "actual visible" workings that one could see, and into which 
one could intervene. In his commitment to "objective" empirical observation, Beale rejected the use of what he saw as figurative language.

For Donna Haraway $(1994 ; 1997)$, however, such an assertion masks a denial. Haraway instructs her readers to be wary of those who deny the rich metaphoricity of scientific vision. To disavow the figural craft of vision is a ruse: all vision depends on "troping" (Haraway 1994, 40; 1997, 141). Following Haraway and Isabelle Stengers (1999, 2008), I'm interested in the exquisite "achievements" of molecular visualization made possible through the invention of new propositions and metaphors in scientific work. For Stengers, abstractions are propositions that ask for and prompt a "leap" of imagination (Stengers 2008, 108-109); and this is so for abstractions like analogies or models. In Stengers' formulation, effective abstractions have "conceptual agency"; they are "lures" that can "vectorize concrete experience," and so lure their makers and users into new "adventures" in knowing $(2008,96)$.

From this perspective, it is apparent that Beale did not recognize the genius of what might be called Huxley's "working conceptual hallucination." 2 In contrast to Beale's transparent, free-moving, intractable bodies, Huxley's machinery was able to produce an alluring object of analysis for the exact scientist. Huxley conceived of a biological object whose properties could, theoretically at least, be quantified. The metaphor of machinery offered Huxley a bridge he could traverse in his imagination between the visible, tangible and manipulable world in which he lived, and the invisible, intangible world of living cells. Here I treat molecular visualization as a "material-semiotic" (Haraway 1994) process. In this sense, it is the "materialized refiguration" (Haraway 1997) of the molecule as a machine that gives the engineer something they can get their hands on, something they can literally grasp. As we shall see below, the machine metaphor would become the enduring analogy that could do the work of luring would-beengineers into the sciences of life.

\section{Getting a Grip on Life Itself}

Enter twenty-first century molecular visualization. Mechanical engineer Geoff Miller ${ }^{3}$ has long been frustrated by the "gooey", intractable stuff of biological inquiry. He collaborates with protein modellers to help them interpret the structural features of the molecules they visualize. He suggests that these researchers are working "in the dark." He explained: "Imagine yourself in a pitch black room. Your job is to figure out what's in the room. You have three or four flashlights. Each has a different frequency of light, and is a different shape and size. One light will show you a spot this big around [Makes a gesture with his hands]. Another will only show flat objects of certain size. Another shines a little bitty spot." Molecular visualization could, in this sense, be understood as a practice of groping around and fumbling in the dark with objects at the limits of

\footnotetext{
2 Gilbert and Mulkay quoted in Lynch (1991).

3 The names of all ethnographic informants have been changed.
} 
the visible, tangible, and imaginable world. As such it is a process of shining select beams of light, grabbing hold of small parts of a larger phenomenon, and cobbling together data to form a picture of the whole.

As protein modellers struggle to "give body" (Hopwood 1999) to molecules and figure out how they work, they model the cell and its substances through tangible analogies, tropes that are ready-to-hand, and familiar to the touch (see Myers 2009b). These are analogies that enable modellers to grasp-to make sense of, to imagine, and to intervene in-otherwise invisible realms. This entails modeling molecules figuratively and materially as those objects familiar to them; and for many, this means modeling them as machines.

Fernando is a protein crystallographer, completing his PhD in a research lab on the east coast of the USA. Fernando is fluent in the rhetoric of molecular machines. He likes to use the metaphor in part because he has a particularly nuanced feel for machines and their parts. He is a latecomer to science, and at forty, he is significantly older than most of the graduate students in his cohort. He grew up in a working class Hispanic family and spent his twenties working as a plumber, manual labourer, and pizza delivery boy, and took much pleasure in building cars. He later went back to school, and started teaching CAD drawing to architecture and engineering students at a community college. Machines are familiar to Fernando: they are, like Beale's clock, "actual visible works" into which he can see and intervene. He understands how they work, how their parts fit together, and what keeps them ticking. Our conversation produced dizzying Alice-in-Wonderland effects of scale as we zoomed along what seemed to be a continuum of visibility, from human-scale machines, down to the scale of molecular machines and back again.

For him, X-ray crystallography is a visualization tool that he uses to "capture" a "snapshot of the machine." He builds models of proteins to figure out what the "machinery" of the cell looks like, and how it works. He describes his job as a protein modeler through an allegorical tale that took us to the factory floor of a robotics-mediated automotive assembly line:

So you know, you are talking about the machine that screws in the fender at the Ford car plant. We're studying that machine because we are trying to find out what it does. And without [the X-ray crystal] structure we are just feeling it, just tentatively, sometimes with big thermal gloves. So we can't really get to feel the intricacies or the nuances of the drill bits. And all of a sudden crystallography is a snapshot of the machine. Okay. It [the machine] can even be in multiple states. Standing still turned off. In a state when there is a screw being drilled into the fender. You know, it can be somewhere in between. Alright? But because we've seen a similar 
machine in another company, we kind of have an idea of what the machine does. We've seen the individual parts and stuff like that. I'm not going to mistake the machine for drilling for the machine for welding. Okay. What crystallography allows you to do is to say, "Hey that is a drilling machine, not a welding machine." Okay. And by looking at certain parts of the machine you can tell whether the drill bit is six inches long or two inches long or whether it has a neck that moves up and down, or whether the neck is static. That's the sort of stuff you get in a crystal structure that you don't have before.

Fernando's image of a human worker whose tactile and visual acuity is dampened by wearing big thermal gloves is an effective analogy that demonstrates how hard it is for the structural biologist to make sense of molecules without the resolving power of both X-ray crystallographic vision and an elaborate "figural vocabulary" to make sense of the substances they draw into view.

Crystallographic modeling gives Fernando both a three-dimensional visualization of the molecule and a "nuanced" "feeling" for its intricate structure (see also Myers 2008). As he made clear during another interview, crystallographic modeling with interactive computer graphic interfaces is, for him, a craft practice through which he has been able to develop what he calls a kind of "touchy-touchy-feel" for the molecular model as he builds it onscreen: "I don't want to say touchy-touchy-feely like that, but that sort of holding on to something and getting a feel of it." Taking off his thermal gloves, so to speak, he uses an interactive computer graphics interface to bring molecules into haptic sensation, as well as into view. And yet, he goes a step further: he draws on his feeling for machines to complete his mechanistic model of molecular structure.

During one of our interviews I asked Fernando if he ever used metaphors other than machines to talk about his proteins. I remarked to him that often I heard structural biologists talk about proteins as wily, animate bodies that "breathe," wriggle and flop around (see Myers 2006). This suggestion put him on edge a little, and his response was firm: "A protein by itself is not a living thing," he tells me. "It is...it is a machine. And it will break down, just like machines do. Okay? And if something is not there to repair it, another machine, another piece of machinery," the whole system will "break down." At the suggestion that proteins had lively qualities, Fernando clamped down firmly on the metaphor of molecular machines. ${ }^{4}$

\footnotetext{
${ }^{4}$ For some insight into what might be at stake for structural biologists in affirming the machine metaphor over body metaphors, see Myers (2007) "Modeling Proteins, Making Scientists." I describe this interview in more depth, and show how figuring molecules as "breathing entities" creates a serious problem for teaching concepts in evolutionary biology. Molecular machine metaphors, in this respect, act like a kind of public relations campaign to keep lay people from
} 
Though he is quite taken by the tools X-ray crystallography affords his curiosity, Fernando is ambivalent about his future in the field. "You can get so fascinated by the intricate gear work of a particular piece," he told me, "that you never learn how to operate the whole machinery." He finds he's very attracted by developments in biological engineering today, which do promise the possibility of "operating" the "whole machinery" of the cell. These are the same kinds of promises that have enticed a large cohort of students to sign up for a new biological engineering major at his university.

Like proteins, metaphors left to their own devices don't automatically crystallize into forms that can produce new meanings and material effects. Like protein crystallographers' efforts to coax proteins to form what they describe as "living, breathing" crystals, metaphors must be nourished and sustained within the context of a practice and a culture that can keep them alive. Not all structural biologists have Fernando's skills with machines. This raises a problem for the emerging discipline of biological engineering. Molecular machine analogies are alluring recruiting devices for rallying would-be engineers into life science practice. Yet, in order to work machines into the cell, and make the machine analogy do work in the cell, educators must engineer biologists who not only have a "feeling for the organism" (Keller 1983), but who also have a feeling for the machine. Thus, to turn their analogies into effective lures, biological engineers must cultivate a dexterity with machines and machinic analogies.

\section{Materializing Molecular Machines}

One hundred years after Huxley first introduced the machine metaphor, it no longer makes audiences swerve. Recall how Fernando successfully sustained the analogy of the cell as the factory floor of the Ford car plant throughout his story. He had such a strong grip on the analogy that there was eventually a slippage from the machine as a metaphor for the molecule, to the molecule that had actually become a machine. It's as if all he had to do was look inside the cell, and there were all the robotics-mediated machines, ready made to do highly specialized kinds of work in the cell.

Some might want to weave a Whiggish historical narrative and suggest that molecular visualization technologies have finally vindicated what could only now be seen as Huxley's daring and provocative premonition of the machinic nature of molecular life. Once molecules' "works" were made as "actual" and tangible as Beale's clock, this history could be trumpeted in a triumphalist tone: "Lo and behold! The molecule has been made manifest-and look for yourself, it really is a machine!" In this move, machines are no longer the animating "lures" that enable the scientist to "leap" across the divide between the visible and the invisible (see Stengers 2008); they are forged into technoscientific fact.

thinking that molecules themselves have agency, as if they might be driving evolution through their affinities and "desires." 
It is by literalizing and so naturalizing machines in the bodies of organisms, and insisting on the neutrality of visualization technologies, that life scientists risk giving the impression that they are merely unveiling life-as-it-really-is. In so doing they disavow the conceptual agency of their analogies and the inventive work that they put into crafting their models and metaphors. Refusing such disavowals, I focus instead on scientists' material-semiotic practices, drawing attention to the achievements of their labours, and to their conceptual and practical dexterity. These investigators have successfully crafted elaborate machine metaphors to turn molecules into visible, tangible, and workable objects. In this sense, molecular visualization is less a form of scientific discovery than an act of conjuring that relies heavily on imagination and handiwork.

\section{Whose Machines?}

My concern is not that machine metaphors reproduce a kind of nineteenth century mechanism or generate a mechanical organism. Indeed, machines are surprisingly lively things (Haraway 1991), and protein modelers' molecular machines are particularly wily (Myers 2006). I am concerned, however, that molecular machines get naturalized as what some structural biologists call "nature's tools," rather than recognized as the elaborately crafted figural machinery of the investigator. In the all-too high stakes game of contemporary US creationism-evolutionary debates, in which proponents of both Intelligent Design $^{5}$ and neo-Darwinian evolution deploy the metaphor of molecular machines with serious deadpan literalism, the question of who made these molecular machines is anything but a trivial matter. The joke, at which neither the creationists nor the neo-Darwinists are in a position to laugh (their silence revealing the depth of their investments), is that these are neither God's clever little devices, nor evolution's sometimes-clumsy concoctions: they are none other than the marvellous conjurings of inventive scientists and engineers who have materialized them through the techniques, aesthetics, and desires of their technoscientific arts.

Curiously, both sides continually defer the responsibility for engineering these little machines to "higher" powers, evolutionary or otherwise: they don't seem to want to take any credit for this crafty work. Yet, if anyone does get the joke, and the absurdity of this denial, it is the biological engineers who are in the midst of struggling to reassert the respectability of "design" and "designers" in

${ }^{5}$ See the Access Research Network website http://www.arn.org/mm/mm.htm for insight into how molecular machines are used by proponents of Intelligent Design. This site hosts a "Molecular Machines Museum," which provides "an introduction to molecular machines and irreducible complexity," complete with animations of molecular machines in the cell, including the bacterial flagellum, whose mechanism, as ID proponents suggest, is far too complex to have evolved through Darwinian processes. The site quotes ID proponent Michael Behe: "A man from a primitive culture who sees an automobile might guess that it was powered by the wind or by an antelope hidden under the car, but when he opens up the hood and sees the engine he immediately realizes that it was designed. In the same way biochemistry has opened up the cell to examine what makes it run and we see that it, too, was designed." 
the realm of life science. Though they may laugh nervously when they speak of ways to "intelligently design molecular machines," they do want recognition for their work-those massive, micro-scale engineering projects that they have rigged up within living cells. Many of them are acutely aware of how molecular machine analogies have been productive of new objects, meanings, and lines of research in their laboratories; and in this they understand well how practices of materialized refiguration sustain their very livelihoods.

\section{Crystallizing Matter and Meaning}

In conclusion, whether proteins are figured as machines, animals, or lively mechanisms (Myers 2006), it is clear that those who practice molecular visualization have never relied exclusively on visual evidence in order to construct models of these subvisible worlds. That is, visualizing molecules is an inventive practice of conjuring metaphors that can provide tenuous, tentative links between that which can be seen, that which can be imagined, and that which-in the context of the particular culture of life science at the time-can be said (see Foucault 1973). To refuse to naturalize the machine in the body of the cell is thus to recognize machine analogies as integral components of the "apparatus of observation" (Barad 1996) that draws molecular structures into view. It is also to assert their role as effective "lures" that enable both leaps of imagination, and tractable means for engineers to get a grip on "life itself" as a quantifiable and manipulable substance. Molecular machines can in this way be made visible as the potent substances they are: that is, as the catalysts that have, in the hands of researchers, worked efficiently and effectively to crystallize matter and meaning, practices and cultures, and ways of life for both proteinacious substances and their scientists.

NATASHA MYERS

Assistant Professor

Department of Anthropology, and

Program in Science and Technology Studies

York University

230 Founders College

4700 Keele Street, Toronto, Ontario

M3J 1P3 Canada

nmyers@yorku.ca

Office: +1-416-736-2100 ext 22394

Fax: +1-416-736-5768

http://www.arts.yorku.ca/anth/nmyers/ 


\section{References}

Barad, K. 1996. Meeting the Universe Halfway: Realism and Social Constructivism without Contradiction. In Feminism, Science, and Philosophy of Science, ed. L. Hankinson Nelson and J. Nelson, 161-94. Boston: Kluwer.

Dawson, J. W. 1883. American Association for the Advancement of Science: Address of the Retiring President, Dr. J. W. Dawson, at Minneapolis, August 15, 1883. Science 2: 190-99.

Foucault, M. 1973. The Birth of the Clinic: An Archaeology of Medical Perception. New York: Pantheon Books.

Fujimura, J. H. 2005. Postgenomic Futures: Translations across the MachineNature Border in Systems Biology. New Genetics and Society 24(2): 195-225.

Gieson, G. 1969. The Protoplasmic Theory of Life and the Vitalist-Mechanist Debate. Isis 60(3): 272-92.

Haraway, D. J. 1994. A Game of Cat's Cradle: Science Studies, Feminist Theory, Cultural Studies. Configurations 2(1): 59-71.

Haraway, D. J. 1997. Modest_Witness@Second_Millennium.Femaleman_Meets_ Oncomouse: Feminism and Technoscience. New York: Routledge.

Harrison, S. 2004. Whither Structural Biology? Nature Structural Biology and Molecular Biology 11: 12-15.

Hopwood, N. 1999. 'Giving Body' To Embryos: Modeling, Mechanism, and the Microtome in Late Nineteenth-Century Anatomy. Isis 90: 462-96.

Huxley, T. H. 1878. A Manual of the Anatomy of Invertebrated Animals. New York: D. Appleton and Company.

Kay, L. E. 2000. Who Wrote the Book of Life?: A History of the Genetic Code, Writing Science. Stanford, CA: Stanford University Press.

Keller, E. F. 1983. A Feeling for the Organism: The Life and Work of Barbara Mcclintock, 10th anniversary ed. New York: W.H. Freeman

Keller, E. F. 1995. Refiguring Life: Metaphors of Twentieth-Century Biology. New York: Columbia University Press.

Lynch, M. 1991. Science in the Age of Mechanical Reproduction: Moral and Epistemic Relations between Diagrams and Photographs. Biology and Philosophy 6: 205-26.

Myers, N. 2006. Animating Mechanism: Animation and the Propagation of Affect in the Lively Arts of Protein Modeling. Science Studies 19(2): 6-30 (Special Issue on the Future of Feminist Technoscience).

Myers, N. 2007. Modeling Proteins, Making Scientists: An Ethnography of Pedagogy and Visual Cultures in Contemporary Structural Biology. Ph.D. Dissertation, Massachusetts Institute of Technology.

Myers, N. 2008. Molecular Embodiments and the Body-Work of Modeling in Protein Crystallography. Social Studies of Science 38(2): 163-99.

Myers, N. 2009a. Modeling Molecular Machines. In NatureCultures: Thinking with Donna Haraway, ed. S. Ghamari-Tabrizi. Cambridge, MA: MIT Press (forthcoming). 
Myers, N. 2009b. Performing the Protein Fold. In Simulation and Its Discontents, edited by S. Turkle. Cambridge, MA: MIT Press (forthcoming).

Stengers, I. 2008. A Constructivist Reading of Process and Reality. Theory, Culture and Society 25: 91-110.

Stengers, I. 1999. Whitehead and the Laws of Nature. Salzburger Theologische Zeitschrift (SaThZ) 2: 193-207. 